\title{
Should we avoid using ketoconazole in patients with severe Cushing's syndrome and increased levels of liver enzymes?
}

\author{
Marine Ollivier, Magalie Haissaguerre, Amandine Ferriere and Antoine Tabarin \\ Department of Endocrinology, University Hospital of Bordeaux, Bordeaux, France
}

\author{
Correspondence \\ should be addressed \\ to A Tabarin \\ Email \\ antoine.tabarin@chu- \\ bordeaux.fr
}

\section{To the Editor,}

We read with interest the paper of Young et al. in which the authors recommend avoiding ketoconazole in the treatment of Cushing's syndrome when patients display increased liver enzymes ( $>2$-fold the upper limit of normal (ULN)) (1).

Severe hypercortisolism is a life-threatening condition and is considered as an endocrine emergency requiring a rapid and dramatic decrease in cortisol levels (2). Ketoconazole and metyrapone, in monotherapy or in association, have been recommended in this instance since they inhibit cortisol synthesis within hours and can normalize cortisol levels within days $(2,3,4)$. Although poorly described in the literature, an increase in liver enzymes, that may be secondary to hepatic steatosis, is a common observation in severe Cushing's syndrome (5). The presence of hepatic metastases may also alter liver function (1). Should we therefore avoid prescribing ketoconazole, a potent life-saving drug in severe Cushing's syndrome, for a risk of idiosyncratic ketoconazole-induced hepatitis that is $<5 \%$ in large series (6)?

We report herein nine cases of ectopic ACTH syndrome (seven males/two females, aged 27-59 years) who presented with intense hypercortisolism (mean urinary free cortisol (UFC) 35.7× ULN, range: 3.8-76.2) associated with increased ALT and/or AST above $2 \times$ ULN (range: 1.6-13.5 and 1.6-2.8, respectively). Five patients had bronchial carcinoids, while an occult tumor, a small-cell lung cancer, a rectal neuroendocrine carcinoma and a metastatic neuroendocrine carcinoma of unknown origin were found in the remaining patients.
Four patients had liver metastasis. Patients received $400-1000 \mathrm{mg} /$ day of ketoconazole (median $=1000 \mathrm{mg} /$ day), associated with metyrapone ( $n=7$; median: $2750 \mathrm{mg} /$ day; range: $500-3000 \mathrm{mg} /$ day $)$ and mitotane $(n=1$; dose: $2500 \mathrm{mg} /$ day). As illustrated in Fig. 1, these treatments induced a rapid, dramatic and sustained decrease in UFC (from 35.7 to $1.0 \times$ ULN after 30 days). Interestingly, AST and ALT levels paralleled those of UFC and decreased from 2.1 to $1.0 \times$ ULN and 3.7 to $0.6 \times$ ULN, respectively 30 days after the start of ketoconazole therapy. No increase in liver enzymes occurred and six of the nine patients had normal transaminase levels at that time.

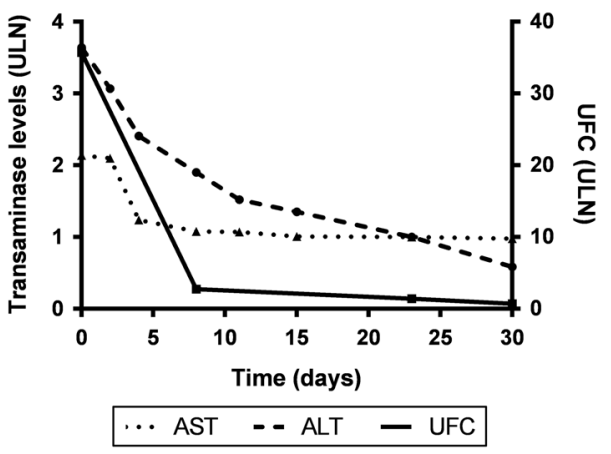

Figure 1

Evolution of mean levels of liver enzymes and UFC during the first month of ketoconazole administration in nine patients with severe Cushing's syndrome. ALT, alanine aminotransferase; AST, aspartate aminotransferase; UFC, urinary free cortisol; ULN, upper limit of normal. 
This small series shows that ketoconazole can be safely prescribed in some patients despite increased levels in liver enzymes. In our opinion, the balance between the risk of severe life-threatening complications in severe Cushing's syndrome should be balanced with the risk of ketoconazole-induced hepatitis. In addition, frequent monitoring of liver enzymes will detect this side effect at an early stage as illustrated by the absence of fatal or serious case of hepatitis in the large FRESKO series (6). Although a rapid decrease in cortisol levels can also be obtained with metyrapone monotherapy (7), the combination with ketoconazole, which acts at different enzymes of cortisol synthesis (8), is probably more efficient when hypercortisolism is intense (3, 4). In conclusion, although limited, our experience suggests that liver function tests may improve during ketoconazole treatment and that, in a life-threatening situation such as severe Cushing's syndrome, increased liver enzymes should not preclude ketoconazole prescription.

\section{Declaration of interest}

The authors declare that there is no conflict of interest that could be perceived as prejudicing the impartiality of this article.

Funding

This research did not receive any specific grant from any funding agency in the public commercial or not-for-profit sector.

\section{References}

1 Young J, Bertherat J, Vantyghem MC, Chabre O, Senoussi S, Chadarevian R, Castinetti F \& Compassionalte use Programme. Hepatic safety of ketoconazole in Cushing's syndrome: results of a Compassionate Use Programme in France. European Journal of Endocrinology 2018178 447-458. (https://doi.org/10.1530/EJE-17-0886)

2 Nieman LK, Biller BMK, Findling JW, Murad MH, Newell-Price J, Savage MO, Tabarin A \& Endocrine Society. Treatment of Cushing's syndrome: an Endocrine Society Clinical Practice Guideline. Journal of Clinical Endocrinology and Metabolism 2015100 2807-2831. (https://doi.org/10.1210/jc.2015-1818)

3 Corcuff J-B, Young J, Masquefa-Giraud P, Chanson P, Baudin E \& Tabarin A. Rapid control of severe neoplastic hypercortisolism with metyrapone and ketoconazole. European Journal of Endocrinology 2015 172 473-481. (https://doi.org/10.1530/EJE-14-0913)

4 Kamenický P, Droumaguet C, Salenave S, Blanchard A, Jublanc C, Gautier J-F, Brailly-Tabard S, Leboulleux S, Schlumberger M, Baudin E et al. Mitotane, metyrapone, and ketoconazole combination therapy as an alternative to rescue adrenalectomy for severe ACTH-dependent Cushing's syndrome. Journal of Clinical Endocrinology and Metabolism 201196 2796-2804. (https://doi.org/10.1210/jc.2011-0536)

5 Hazlehurst JM \& Tomlinson JW. Mechanisms in endocrinology: nonalcoholic fatty liver disease in common endocrine disorders. European Journal of Endocrinology 2013169 R27-R37. (https://doi.org/10.1530/ EJE-13-0296)

6 Castinetti F, Guignat L, Giraud P, Muller M, Kamenicky P, Drui D, Caron P, Luca F, Donadille B, Vantyghem MC et al. Ketoconazole in Cushing's disease: is it worth a try? Journal of Clinical Endocrinology and Metabolism 201499 1623-1630. (https://doi.org/10.1210/jc.2013-3628)

7 Verhelst JA, Trainer PJ, Howlett TA, Perry L, Rees LH, Grossman AB, Wass JAH \& Sesser GM. Short and long-term responses to metyrapone in the medical management of 91 patients with Cushing's syndrome. Clinical Endocrinology 199135 169-178. (https://doi.org/10.1111/j.1365-2265.1991.tb03517.x)

8 Pivonello R, De Leo M, Cozzolino A \& Colao A. The treatment of Cushing's disease. Endocrine Reviews 201536 385-486. (https://doi. org/10.1210/er.2013-1048)

Received 17 August 2018

Accepted 30 August 2018 